\title{
THE 3DP - THREE-DIMENSIONAL PRINTING - IS IT A REAL PROSPECT OF AUTOMATING THE BUILDING PROCESSES?
}

\section{ЗDР - ТРИВИМІРНИЙ ДРУК - ЧИ Є ВІН РЕАЛЬНОЮ ПЕРСПЕКТИВОЮ АВТОМАТИЗАЦІЇ БУДІВЕЛЬНИХ ПРОЦЕСІВ?}

Olena Chernieva, Ph.D. in Engineering, Associate Professor, (Odesa State Academy of Civil Engineering and Architecture), Andrzej Wojnar, Ph.D. in Engineering, Assistant Professor (Rzeszow University of Technology, Poland), Sara Pogan, Eng. student, (Rzeszow University of Technology, Poland)

Чернєва О.С., к.т.н., доц. (Одеська державна академія будівництва та архітектури), Andrzej Wojnar, к.т.н., асистент (Жешувський технологічний університет, Польща), Sara Pogan, студент, (Жешувський технологічний університет, Польща)

The construction industry is particularly well-suited to take the advantages of the 3DP technology however it still seems to be a distant perspective. The method itself, allows to manufacture prefabricated elements, small landscape facilities and detached houses, pedestrian bridges (of relatively little span lengths) etc. On that field, the considered technology is already prospering. Furthermore, the technology is a great solution for scale models used by architects. The 3-Dimensional print turned out to be a quick and an almost unbeatable way of presenting a concept to the potential investors. The visualization of the project became easier, giving an exact mapping of the surroundings and the structure itself, which helps to eliminate the risk of possible architectural or constructional mistakes. The technology facilitates the implementation of any needed amendments, whereas the scale models became one of the verification ways of the project's documentation and the building's proportions. However, more research and law regulations are needed to state the final applicability and limitations of the presented technology. Ensuring the mechanical properties along with the quality control work together to provide us with safe elements for the use of large-scale engineering. The article presents the application of $3 D$ printing technology in construction and bridge engineering. Available technologies and methods of printing objects were presented. Examples of structures made of various materials are presented: concrete, steel and synthetics. The features of an emerging 3-dimensional monolithic objects are conditioned upon the used software advancement, printing technology, the printer used and the material applied. In the mentioned construction industry, where the labour workload becomes an increasingly significant component in the final cost of the construction project, the 3DP could revolutionise the whole process of the execution methodology. The ,complexity and universality” of a facility and its execution method is being understood as an increased number of openings, irregular and complex shapes, the precision of the formed elements, fragments or segments and efficiency of the technology used. (Review article) 
Будівельна галузь особливо добре підходить для того, щчоб скористатися перевагами технології $3 D$ друку, яка, однак, все ще здається віддаленою перспективою. Сам спосіб дозволяє виготовляти збірні елементи, невеликі ландшафтні споруди та окремі будинки, пішохідні мости (відносно невеликої довжини прольоту) тощзо. В иій галузі ияя технологія вже процвітає. Крім того, ия технологія є чудовим рішенням для масштабних моделей, якими користуються архітектори. Тривимірний друк виявився швидким $i$ майже неперевершеним способом представлення концепиії потенційним інвесторам. Візуалізація проекту стала простішою, даючи точне відображення оточення та самої структури, щзо допомагає усунути ризик можливих архітектурних чи будівельних помилок. Ця технологія сприяє впровадженню будь-яких необхідних поправок, тоді як масштабні моделі стали одним із способів перевірки документації проекту та пропориій будівлі. Однак потрібно більще законодавчих нормативно-правових актів щуодо досліджень, щуоб констатувати остаточну область застосування та обмеження представленої технології, забезпечити контроль якості та праці для безпечного використання широкомасштабної техніки у будівельній галузі. Стаття знайомить нас з сучасними технологіями $3 D$ моделювання. Автори аналізують переваги та недоліки даної методики, наводять реальні приклади застосування 3D друку із використанням бетонних, металевих та синтетичних матеріалів. Якість тривимірних монолітних об'єктів залежить від розвитку використовуваного програмного забезпечення, технології друку, принтера $i$ будівельного матеріалу, який при цььому використовується. Таку технологію зручно застосовувати, коли об'єкт є складним та унікальним. Під «складністю $i$ унікальність» об'єкта і способу його виконання розуміється збільшена кількість отворів, неправильна або складна форма об'єкту, точність сформованих елементів, фрагментів або сегментів, економічно обтрунтована ефективність технологіі. (Стаття оглядова)

Keywords: $3 D$ printing, 3D construction technology

Ключові слова: $3 D$ друк, 3D будівельні технологї

Introduction. The future of civil engineering is unquestionably the BIM (Building Information Modelling), the ecological engineering, recycling, the automation of building processes, implementing the prefabricated elements and the 3DP (Three-Dimensional Printing). The 3DP builds (prints) a 3-Dimensional object basing on computer-aided design (CAD) - model data. It is done by additive, gradual layering of the used material - filament - layer upon layer. The term itself ,3D Print" regards to a variety of processes, where the material is either fused or consecutively bonded together as the computer supervises the procedure in order to create a three-dimensional solid object.

In the 90's, the 3D printing techniques were acknowledged only for the use of functional or esthetical prototype productions, also known under the 'Rapid Prototyping' term. Since 2019, the precision, repetitiveness and the range of possible to use materials have grown to the point, where some processes of $3 \mathrm{D}$ printing have started to be considered as a viable technology of producing 
problematical shapes and complex geometry, therein empty parts or parts with an internal truss structure, made in order to reduce the burden. All that set for implementing to the production processes of any type of parts - under the precondition of an existing digital 3D model.

The features of an emerging 3-dimensional monolithic objects are conditioned upon the used software advancement, printing technology, the printer used and the material applied. If the ,complexity and universality” of a facility and its execution method is being understood as

- an increased number of openings

- irregular and complex shapes,

- the precision of the formed elements, fragments or segments,

- efficiency of the technology used.

Then the 3D printing method allows cost reduction due to its limited material use as well as the need of using extra devices or tools. The mentioned technology narrows down the needed interference of human labour, which positively affects the general costs of the construction project and increases the safety of construction processes. The minimalized material uses and the labour costs, that grow each year, are putting the technology in a promising light and increase its competitiveness against traditional methods.

The numerous advantages of the 3DP are making it an increasingly used method in the automotive branch as well as the medical area. It's huge potential has also been seen in the military field and the civil engineering society (road and bridge engineering). In the mentioned construction industry, where the labour workload becomes an increasingly significant component in the final cost of the construction project, the 3DP could revolutionise the whole process of the execution methodology.

Technology. Concerning the industrial use, the 3DP technology is evolving on different fields - new, advanced materials are developing, further research is done to improve quality, the possible workfield is being constantly enlarged and the extensive research on new layering technologies - additive manufacturing - is progressing.

The technology choice is made based on the printers' expenses, the expected print time, it's quality and the service-related parameters. In order to design the target model, the Computer Aided (CAD) softwares are being used. It is also possible to use 3D scanners, which allow you to scan the selected object, which may be then replicated using the 3D print technologies. Currently used softwares, helping with the digital model designing processes, are, for example the Solidworks, Blender, Tinkercard or the Autodesk 123D [1]. The created digital model is then transferred to the printer in a stereolithographic language (STL - Standard Tesselation Language) - which is a format that can be used in the additive manufacturing processes, or an AMF one (Additive Manufacturing File Format). 
The most popularised 3D printing technologies for additive manufacturing are listed below:

- FDM (Fused Deposition Modeling) - a technology that allows to print out objects by layering the melted thermoplastic material. However, only limited material range can be used;

- The Contour Crafting - a technology based on a cartesian (X,Y,Z) machine consisting of a nozzle supported by a gantry system, which moves in two parallel lanes. It follows the target contour of the modelled facility, consecutively layering the material;

- CJP - a printing technology using a plaster-based powder material. The creation process of the models in the CJP (ColorJet Printing) is based on a selective bondage of the powdered material with liquid binders. The printing speed, relatively low costs as well as the possibility of a multicolour print are the main advantages of the mentioned technology;

- Binder Jetting - this technology, just like the CJP, is based on the usage of liquid binders, which bond together materials such as sand, metal or ceramics. It is characterized by a high efficiency, which makes the Binder Jetting a relatively popular industrial technology. It is commonly used in the form manufacturing as well as in the foundry core production;

- SLA (Stereolithography) - a technology using a liquid photopolymer resin, solidified by a laser beam;

- DLP - Digital Light Processing - a technique based on curing liquid resin under a light source, emitted by the digital light projector. A visible drawback of this technology is its boundaries regarding bigger objects (where either the length or the width exceeds a dozen centimetres), when a significant shrinkage of the cured resin is occurring during the printing process;

- SLS - Selective Laser Sintering - a 3D printing technology that utilises a laser to melt successive layers of powdered components (usually polyamides);

- SLM/DMLS - a 3D print technology fusing metal powders with a laser beam;

- EBM - Electron Beam Melting - a 3D printing technology, similar to the SLM/DMLS, where instead of a laser beam power source, an electron beam is used to fuse conductive metal powders;

- MJF - Multi Jet Fusion technology (invented by HP), where powdered synthetical materials (mainly polyamides) are used.

In the civil engineering industry, the FDM technology (used mainly in the prefabricated elements manufacturing), as well as the Contour Crafting technique (used for the in-situ printing) seem to be the most ubiquitous, see Fig. 1. Different ways of 3D printing buildings are presented in Fig. 2 to 4. 
"Сучасні технології та методи розрахунків у будівництві", випуск 13, 2020

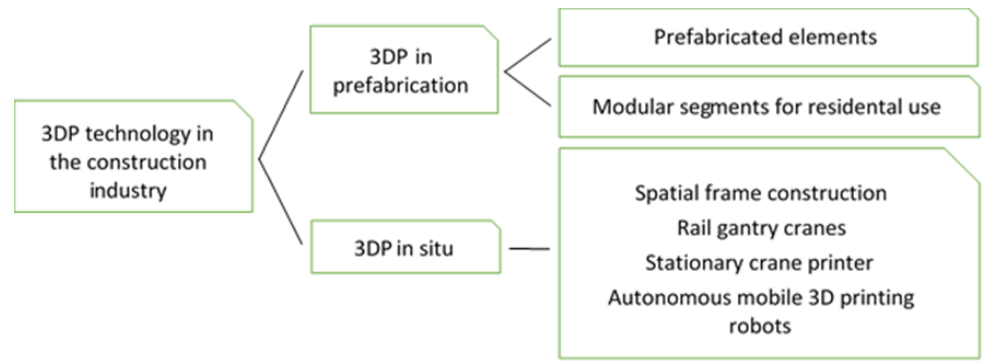

Fig. 1. 3D printing technology in the construction industry

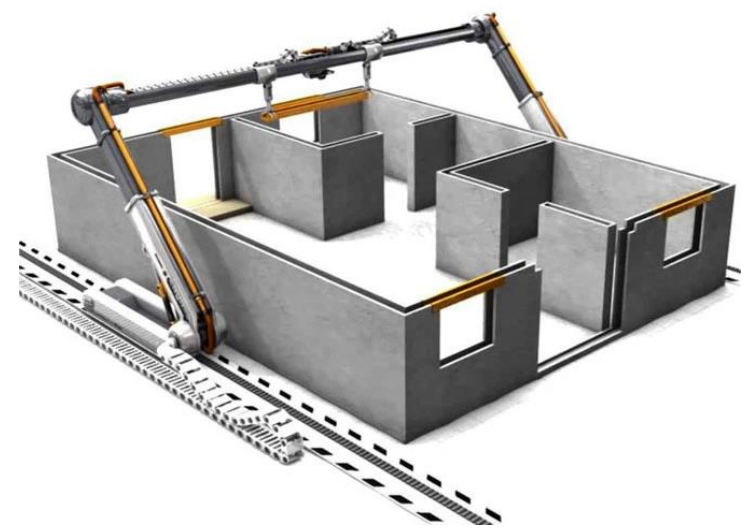

Fig. 2. Housing - in the 3DP technology

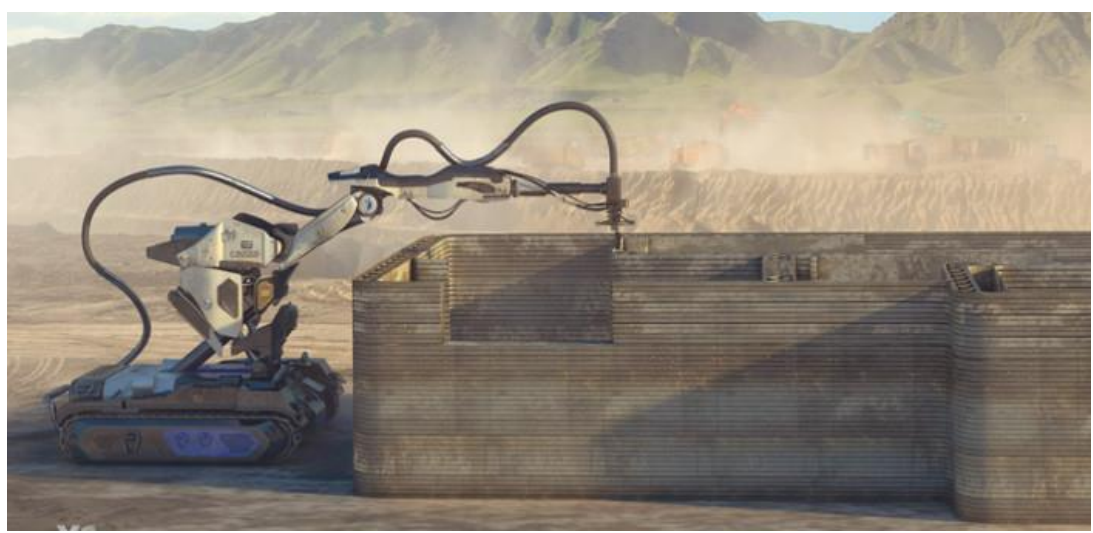

Fig. 3. A 3DP unit for large-scale construction 


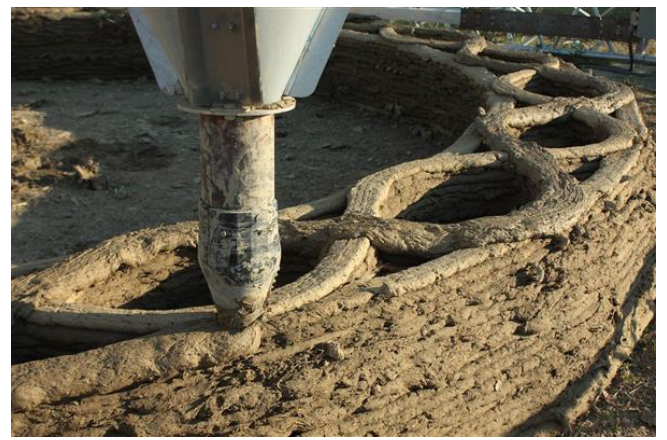

Fig. 4. 3D printing in civil engineering

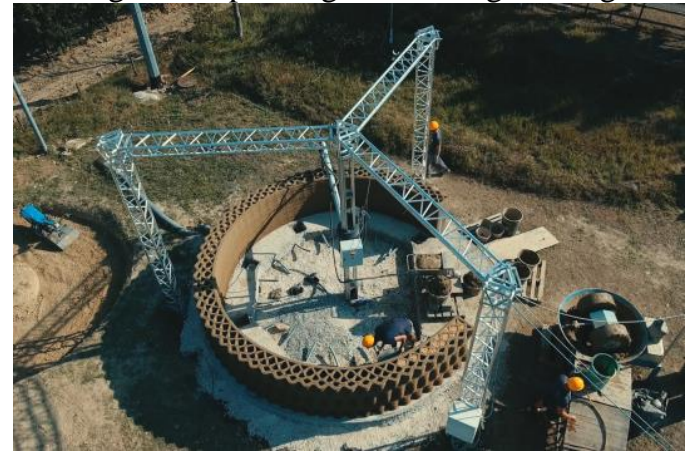

Fig. 5. Construction industry 3DP in-situ

The 3D printing with concrete use. Most companies working in the 3DP branch have mastered the extrusion of concrete mixes to an extent which makes it possible to print small objects. However, it is not a satisfying stage of advancement when it comes to a large-scale engineering. The knowledge of properties of the produced prefabricates or large-scale parts of the construction working as one - is absolutely crucial. It is also essential to determine the load and temperature resistance as well as the materials' abrasion and fatigue which are the few basic mechanical properties achieved in each 3D printing technology. A substantial fact is that both the density and the type of the filling of the created structure, along with the printing temperature have a significant influence on the structures' durability. For instance, the FDM technology allows us to manufacture porous structure elements, which reduce the usage of the base material. However, a change in the structure results in a change of the mechanical properties of the produced object. When checking the construction's behaviour, we should be guided by the materials' parameters for the emerging structures, resulting from a certain technology used to manufacture. The researches carried out so far prove, that for the printed elements, we should be considering the material parameters obtained experimentally - not the initial 
filaments' (components used for the printing process) ones. The discrepancy between them is too significant to be taken as negligible.

For the 3D printing technology in civil engineering the researches focused on developing techniques with the use of cement and concrete mixes as possible filaments. These are especially compelling. Parameters such as the aggregate's grain, the consistency and workability of the mix, and the parameters of buildability - that allow building up subsequent layers are particularly important. All the mentioned factors have to undergo quality control. However, a whole series of questions arises regarding the constructional issues - such as the automated reinforcement process, the support structure solutions, the lintel manufacturing etc. and whether it could be done using the 3DP technology as well - in order to fully automatize the construction processes. It seems to be the biggest obstacle, therefore a challenge, for the concerned technology, to implement it in the civil engineering society and large-scale projects.

Presently, the research focuses on the possible use of the FRC (Fiber Reinforced Concrete) technology, the influence of the rheological properties of concrete, the comparison of the standards' approach and its relation and applicability to the 3DP solutions. Ongoing research is also carried out when it comes to the possibility of fiber orientation, since 'the higher the orientation index, the higher bending resistance' is achieved (in the fibers' direction). The lack of randomness is also desired due to the possible reduction of constructions' cracking.

It should also be mentioned that because of the relative indifference when it comes to the complexity of the project's geometry, the 3DP technology can reduce the material used in the cross-sections, where the internal forces do not require the same dimensions of the cross-section as in the most critical parts of the concrete construction [2, 3]. Local reduction of the cross-section's dimensions, in traditional methods, is not only complicated but also economically unfeasible. Examples of houses made of concrete printed in 3D technology are shown in Figs. 6 to 9. Examples of bridge structures in Figs. 10 and 11.

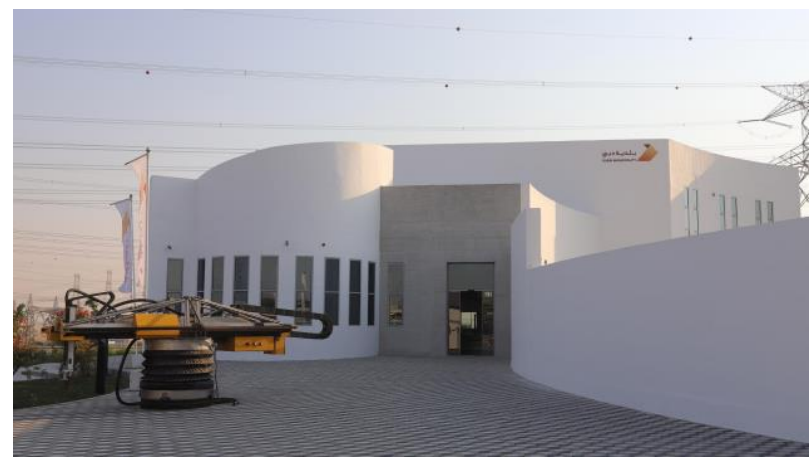

Fig. 6. A facility made in the 3DP technology in Dubai [2] 
"Сучасні технології та методи розрахунків у будівнццвві", випуск 13, 2020

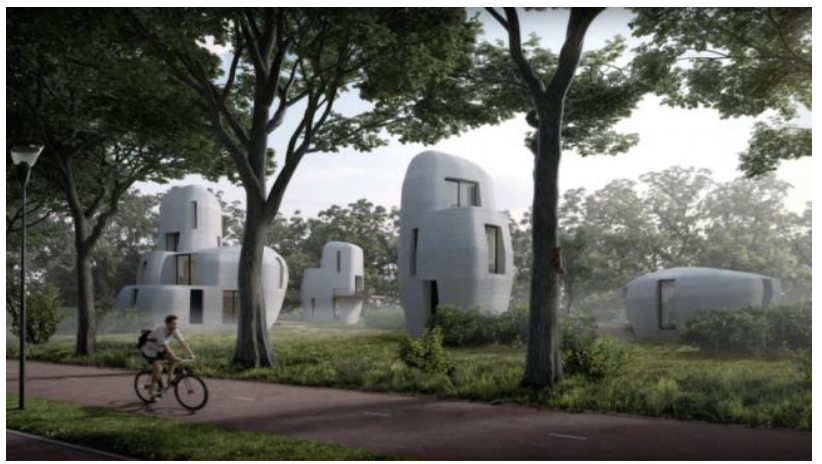

Fig. 7. Printed houses - Australia

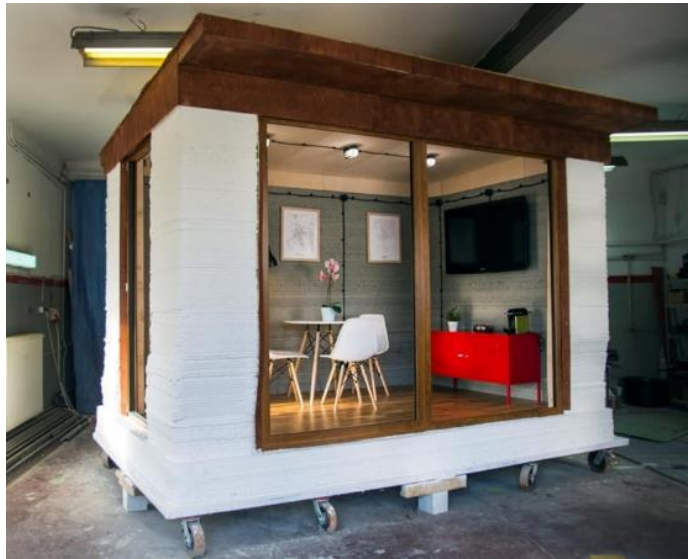

Fig. 8. The first house created in the 3DP technology in Poland

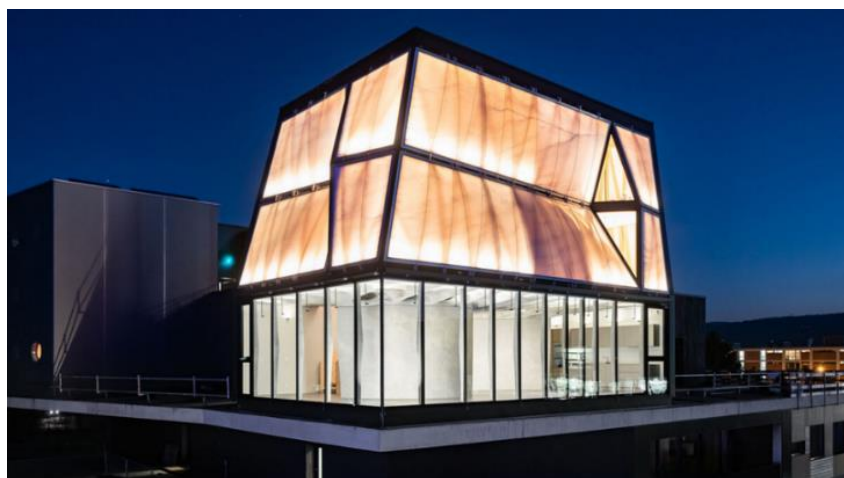

Fig. 9. DFAB House, in Dübendorf - the first inhabited house made in a 3DP technology 


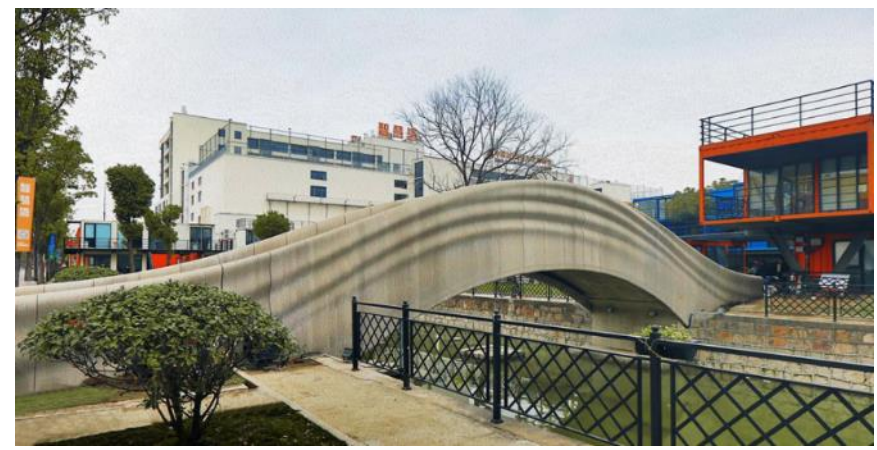

Fig. 10. Shanghai - a concrete bridge with a 26 meters long span is currently the longest bridge made in the 3D print technology.

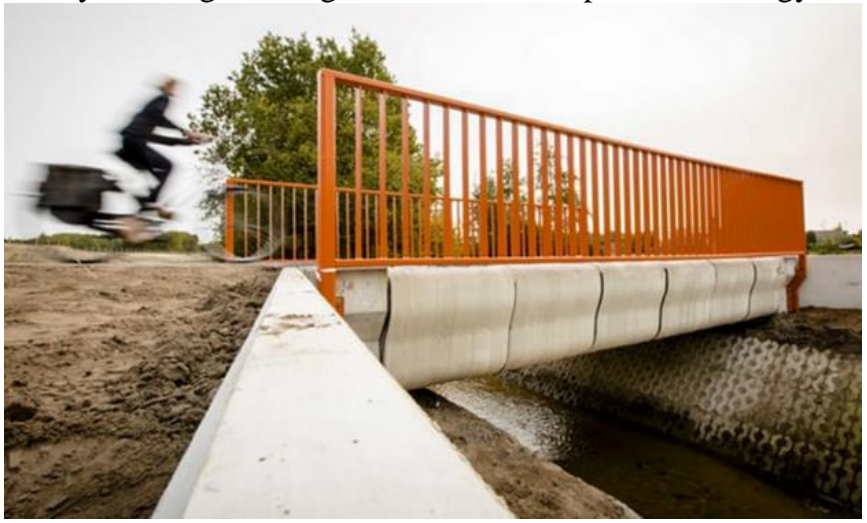

Fig. 11. A prestressed concrete bike bridge in the Netherlands, reinforced with fibers

Metal 3D printing. A significant development in the 3D technology has also been spotted in the construction processes using steel as it's building material. This 3D printing technology uses laser to bind powdered materials including metals $[4,5]$. The high-powered laser emits a laser beam that heats the powder to bind together it's particles, which are then dispersed in thin layers. The technology is called SLM - which stands for Selective Laser Melting. After the printing process is done, selected parts go through a heat treatment. This technology connects the desired freeform design feature with good mechanical properties. It also significantly reduces the construction time because it is quicker than traditional foundry processes thanks to the direct data use from the CAD softwares. It could reduce the needed assembly time and costs as well. A visible drawback of the presented method is the cost of the needed industrial printing units' components for 3DP (with the use of metal) - such as the galvanometric scanner or the iterbic laser. Other, commonly known, metal 3DP 
technologies are the EDB, DMLS/SLM or the Laser Cusing. An example of a metal bridge designed and made in 3D printing technology is shown in Fig. 12.

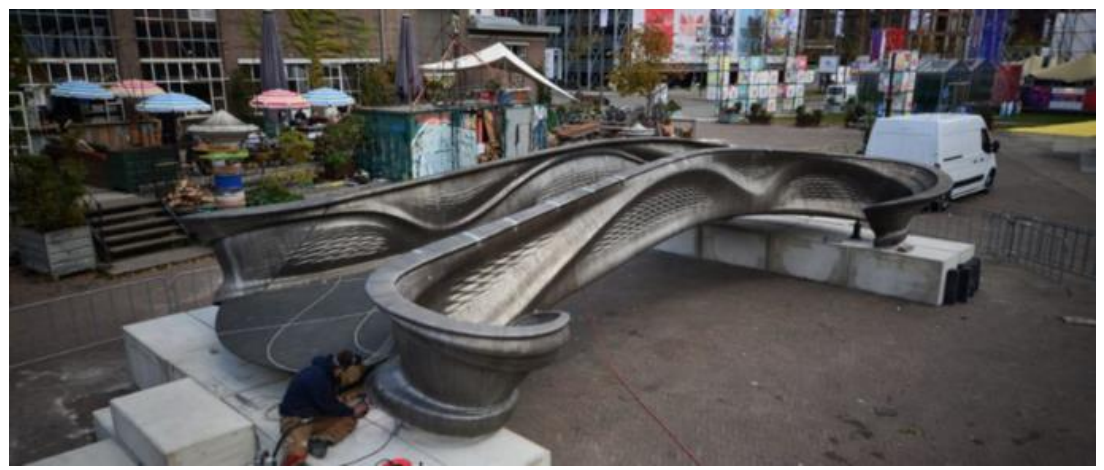

Fig. 12. A stainless-steel bridge construction, made with the use of an automated 3D print technology

The 3DP with the use of synthetics. Synthetics are processed at operating temperatures, to up to $300^{\circ} \mathrm{C}$ - depending on the technology and the type of the printing device used. The used filaments should be brought to a semiliquid state. Currently the most frequently used materials in the presented technology are polymers - PA6, PBT, PET, PPS. PEKK and many others. Carbon or glass fibers as well as aluminium or components which reduce the flammability are common additions to the polyamides (PA). This enables the interference in the final stiffness, flammability or the anisotropy of the desired material. The printing technologies used with synthetics are the SLS, SLA or FDM. They are all an alternative option for injection moulded products, implementing the wanted freeform designing to the formation processes.

The SLS technology provides good isotropic mechanical properties, a flexible design approach, a high durability of the element, high performance (in accordance with the DIN EN ISO 286-1), easy processing as well as the possibility to re-use unbound particles of the powder. However, it is not a flaw free technology. The SLS printed elements are vulnerable to shrinkage and deformation - so the grooves and small openings are harder to print.

The FDM technology uses materials such as ABS, ASA, PLA, PET or nylon. It is based on selective settling of the plasticized material (in the nozzle the material heats to the temperature of $180-260^{\circ} \mathrm{C}$ ) on the bed. Some extra supporting structures are often needed. There is also an increase of interest in the production with the use of filaments based on thermoplastic elastomers (TPE) - especially in medicine - tissue engineering, as well as in the electronics branch. The ability to modify the mechanical properties of the mentioned 
filaments, along with the processability properties accelerates the still growing interest in this technology.

Answering the needs of elements bearing with special requirements, it is possible to use polymer materials with added strengthening components (fibers etc). It is surely a high potential and very promising technology, considering the fast development of the composite construction designs. An example of this is the footbridge with a span of $11 \mathrm{~m}$ shown in Fig. 13.

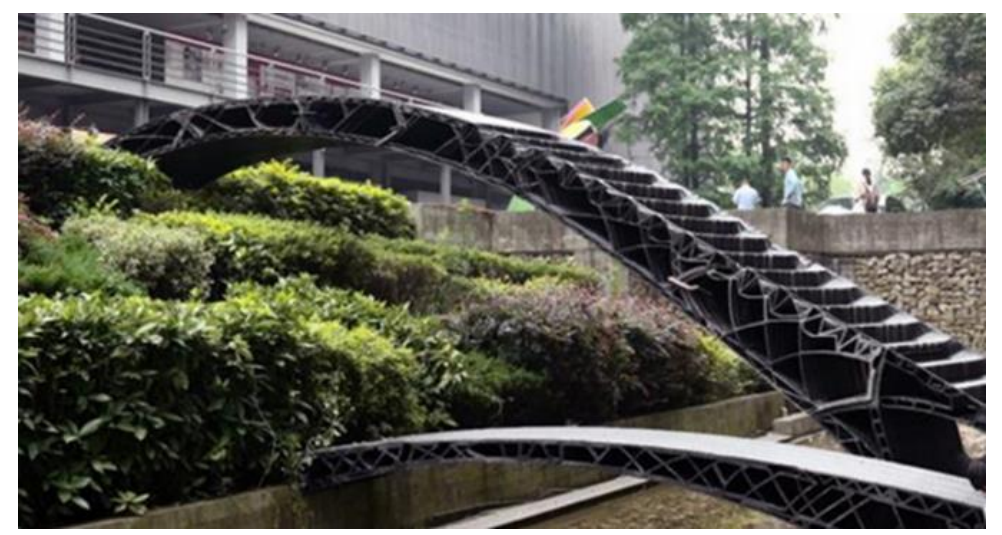

Fig. 13. A pedestrian bridge made of plastic in the 3D print technology, where the span measures 11 meters

Conclusion. The construction industry is particularly well-suited to take the advantages of the 3DP technology however it still seems to be a distant perspective. The method itself, allows to manufacture prefabricated elements, small landscape facilities and detached houses, pedestrian bridges (of relatively little span lengths) etc. On that field, the considered technology is already prospering. Furthermore, the technology is a great solution for scale models used by architects. The 3-Dimensional print turned out to be a quick and an almost unbeatable way of presenting a concept to the potential investors. The visualization of the project became easier, giving an exact mapping of the surroundings and the structure itself, which helps to eliminate the risk of possible architectural or constructional mistakes. The technology facilitates the implementation of any needed amendments, whereas the scale models became one of the verification ways of the project's documentation and the building's proportions. However, more research and law regulations are needed to state the final applicability and limitations of the presented technology. Ensuring the mechanical properties along with the quality control work together to provide us with safe elements for the use of large-scale engineering. In the end it is worth to list down the main advantages and disadvantages of the 3DP 
Advantages:

- $\quad$ Reduces power usage by up to $70 \%$ compared to traditional methods,

- $\quad$ produces less waste,

- $\quad$ possible use of recycled materials,

- high precision performance of the created elements,

- $\quad$ uses less labour lowering its cost in the general cost of the construction project,

- reduces the needed equipment on the construction site,

- $\quad$ increases the general safety in the construction industry,

- $\quad$ possible to use at night.

Disadvantages:

- questionable feasibility of the technology regarding not very complex projects,

- confusing procedures of the digital construction modeling processes,

- the costly development of concrete mixes - cement composites,

- no completed endurance tests of the used materials,

- unregulated legal aspects,

- $\quad$ relatively low availability of the possible materials and printing units.

\section{References}

[1] http://www.javelin-tech.com/3d-printer/industry/architecture/

[2] http://3dprinting.com/news/winsun-3d-printed-giant-apartmentbuilding-villa/

[3] http://3dprint.com/38144/3d-printed-apartment-building/

[4] http://www.dezeen.com/2015/10/19/joris-laarman-3d-printed-canalbridge-amsterdam/

[5] http://swiatdruku3d.pl/robot-samodzielnie-wydrukuje-stalowy-most-wpowietrzu/ 